\title{
Novel human partner cell line for immortalisation of rare antigen-specific $B$ cells in $\mathrm{mAb}$ development
}

\author{
Galina Kaseko*, Marjorie Liu, Qiong Li, Tohsak Mahaworasilpa \\ From 22nd European Society for Animal Cell Technology (ESACT) Meeting on Cell Based Technologies \\ Vienna, Austria. 15-18 May 2011
}

It is well-documented that post-translational modification (PTM) events, such as glycosylation, play an important role in antibody-dependent cell-mediated cytotoxicity (ADCC) [1,2]. In current technological processes, monoclonal antibody (mAb) production is widely achieved using heterologous hybridoma systems or genetic engineering using various non-human cell lines as expression host. As a consequence, PTMs generated from non-human cell lines may differ from their human counterparts, resulting in diminished antibody efficacy, aberrant folding and adverse immunogenic response. Therefore, the use of human partner cell lines to generate "fully human" mAbs is beneficial as it circumvents functional complications associated with non-human cell lines.

A human cross-lineage hybrid cell line was developed in our laboratory as a candidate partner for immortalisation of rare primary human antigen-specific B lymphocytes using binary electrical cell hybridisation technique which has been developed in house. This novel partner cell line is a tri-hybrid of IL-4 secreting Th2 lymphoblast derived from a patient with acute lymphoblastic leukaemia (T), $\mathrm{CD} 20^{+}$B lymphoblast, also derived from a patient with acute lymphoblastic leukaemia (W), and IL-6 secreting peripheral blood-derived CD $14^{+}$monocyte (M). The selection of cell phenotypes used to create the tri-hybrid was based on factors known to maintain and promote antibody production.

The resulting tri-hybrid (WTM) displayed characteristics of mixed $\mathrm{CD}$ phenotypes with the majority of cells being $\mathrm{CD}^{2} 0^{+}(95 \%)$ with co-expression of $\mathrm{CD}^{+}(54 \%)$

\footnotetext{
* Correspondence: g.kaseko@ssri.org.au

The Stephen Sanig Research Institute, Suite G17, National Innovation Centre, Australian Technology Park, 4 Cornwallis Street, Eveleigh, NSW, 2015, Australia
}

and $\mathrm{CD}_{14}{ }^{+}(24 \%)$. It secreted IL-4, IL-6, IL-8 and GMCSF but was negative for IL-1A, IL-1B, IL-2, IL-5, IL-10, IL-12, IL-13 and IL-17. The cell line did not express the tumour suppressor protein, $\mathrm{p} 53$, and neither did it secrete immunoglobulins (Ig)/ Ig chains nor were they expressed on the surface.

WTM cells were then used as a fusion partner with primary antigen-experienced $\mathrm{CD} 19^{+} \mathrm{B}$ cells which had been isolated from peripheral blood, activated in vitro, and the resultant hybrids were sorted for $\operatorname{IgM}^{+}$and $\operatorname{IgG}$ + expression. 100\% hybridisation success rate was achieved using a binary electrical cell hybridisation technique and the number of resulting stable hybrids varied from $48 \%$ to $78 \%$ depending on the phenotype of B lymphocytes used in experiments. $23 \%$ to $68 \%$ of those stable hybrids secreted Ig with production ranging between 0.2 to $1.2 \mathrm{ìg} / 10^{6}$ cells (Table 1 ). Cytokine screening of some of the Ig producing hybrids revealed a cytokine profile which was inherently different to that of the WTM partner cell line. The Ig producing hybrids concurrently expressed IL-10 and GM-CSF but not IL4 , IL-6 or IL-8. These hybrids were also positive for TGF-â, RANTES, MIP, MCP and MDC.

In conclusion, major advantages of our method involve the rapid generation of stable Ig producing hybrids from a small B lymphocyte population size (50 cells) and the elimination of conventional laborious screening methods for hybrids and Ig producing clones. Thus, when the number of rare antigen-specific B cells available is a limiting factor in generating hybridoma, EBV transfection or direct sequencing, binary electrical B lymphocyte hybridisation with WTM cells can provide a very attractive approach for the generation of stable hybrid cell lines producing monoclonal antibodies. 
Table 1 Success rate of stable hybrid generation and Ig producing hybrids

\begin{tabular}{lll}
\hline Event & Success rate, & \\
\hline Hybridisation & 100 & $(\%)$ of attempts \\
Stable hybrids & 48 & $(\%)$ of hybridised \\
lg producing hybrids & 23 & $(\%)$ of stable hybrids \\
\hline
\end{tabular}

Published: 22 November 2011

\section{References}

1. Raju TS: Impact of Fc Glycosylation on Monoclonal Antibody Effector

Functions and Degradation by Proteases. In In Current Trends in

Monoclonal Antibody Development and Manufacturing Biotechnology:

Pharmaceutical Aspects. Volume XI. NY 3, USA: Springer Science + Business Media;Shire S 2010 1001:(6):249-269.

2. Werner RG, Kopp K, Schlueter M: Glycosylation of therapeutic proteins in different production systems. Acta Paediatri 2007, 96:17-22.

doi:10.1186/1753-6561-5-S8-P130

Cite this article as: Kaseko et al:: Novel human partner cell line for immortalisation of rare antigen-specific $B$ cells in $\mathrm{mAb}$ development. BMC Proceedings 2011 5(Suppl 8):P130.

Submit your next manuscript to BioMed Central and take full advantage of:

- Convenient online submission

- Thorough peer review

- No space constraints or color figure charges

- Immediate publication on acceptance

- Inclusion in PubMed, CAS, Scopus and Google Scholar

- Research which is freely available for redistribution

Submit your manuscript at www.biomedcentral.com/submit 